\title{
Exploring The Influencing Factors Of Teachers' Beliefs Toward The Use Of Multiple Intelligences Based English Teaching
}

\author{
Ririn Tutik Faidah \\ Sebelas Maret University \\ Surakarta, Indonesia \\ Endang Fauziati \\ University of Muhammadiyah Surakarta \\ Surakarta, Indonesia \\ Suparno \\ Sebelas Maret University \\ Surakarta, Indonesia
}

\begin{abstract}
Teacher beliefs become an important part of the teachers in the instruction process. In shaping their beliefs, teachers are influencing by many aspects around them. Those aspects are considered essential in shaping the teachers beliefs on how to act in the classroom practice. This study aims to find out the contributing factors in shaping the primary teachers beliefs toward the use of multiple intelligences based English teaching. The participants of this study were two primary English teachers who have been teaching with multiple intelligences based instruction for more than 3 years in a private primary school which run multiple intelligences system. The results showed that there are two main factors shape the teachers' beliefs on multiple intelligences based English teaching. Those main factors were the internal factors and the external factors. Those factors give important contribution in shaping the teachers beliefs when implements the multiple intelligences based English teaching in the classroom practice.
\end{abstract}

Keywords: Teachers Beliefs, influencing factors, multiple intelligences, English Language Teaching

\section{INTRODUCTION}

Studies on multiple intelligences theory as a based approach for language teaching have been increased recently. Those studies reported that teachers play an important role to run multiple intelligences method in the instruction process. The teachers are required to create student centre learning and manage their classroom effectively by creating MI based lesson plans, MI based strategies, MI based activities and MI based Assessment (Celik, 2015; Chatib, 2013; Hoerr, 2000; Armstrong, 2009). Therefore, teachers play an important role for implementing the multiple intelligences system in the instruction process. In implementing the multiple intelligences system for the instruction, teachers have to use their beliefs in this method of teaching to determine what will they do, teach, assess, and how to handle the students and the environment in the classroom actions. Thus, in this case, teachers' beliefs contribute much on determining the teachers' practice in the classroom.

Bedir (2010, p. 5208) stated that teachers' beliefs have strong implications for the way they practice teaching. Teachers' beliefs become the principle views that guide teachers' expectation about the students' behaviour, students' multiple intelligences, and students' learning style and 
decision they make during the lessons. Those beliefs are shaped and acquired by many factors from the teachers themselves and the school environment around them. Therefore, this study seeks to explore the contributing factors that shape teachers beliefs within the implementation of multiple intelligence based English teaching for young learners.

\section{Aim of the Study}

This study aims to identify the contributing factors which shape teachers' beliefs on multiple intelligences based English teaching for young learners. This study is conducted in a private primary school in Surakarta city which runs multiple intelligences system in its instruction process.

\section{Teachers Beliefs}

\section{LITERATURE REVIEW}

Belief is a key that influence teachers' views, understandings, and values. Many researchers define beliefs in many different ways. Pajares (1992) defines belief as "an individual judgment of the truth or falsity of a proposition, a judgment that can only be inferred from a collective understanding of what human being say, intend and do" (p. 316). Additionally, Borg (2003, p. 81) defines teachers beliefs as unobservable cognitive dimension of teaching. He uses the term teachers' cognition rather than teacher beliefs to define what the teachers know, believe, and think.

Moreover, Yero (2002, p. 21) states that belief is judgments and evaluations that we make about ourselves, others, and the world around us. Additionally, Ismail (2007, p. 62) defines beliefs as the frame of people's actions, its variety of meanings refers to agendas of the researchers and the aim of the studies. Moreover, Xu (2012, p. 1398) stated that a teacher's beliefs is a teacher's self-instruction, which is accumulated from social history and culture, personal-experience and education, the teachers' teaching ability and the students.

From the definitions above, it can be concluded that teachers' beliefs is teachers' knowledge, judgments and thinking which influence teachers' behavior in the classroom. Teachers beliefs also play a fundamental framework to make a decision about what will they do in teaching.

\section{Factors Influencing Teachers Beliefs}

As we know teachers' beliefs becomes an important role for the teachers itself in the instruction process. In this study, teachers' beliefs can be acquired from many aspects which influence to shape those beliefs. According to Woods (1996) there are two factors that influence and shape teachers' decision-making process, those are external and internal factors. The external factors are situational factors which teachers take consider about it to make a decision (or to be accurate, what teachers know, assume, and believe about these factors). The external factors influence teachers when they face specific situations or specific events that lead them to make a decision based on their knowledge (p.16). Woods (1996, p. 129) gives an example of some external factors of a teacher when he took pre-lesson decision-making that should consider:

1. How many students will probably turn up

2. Availability of photocopying machine

3. Knowledge about students' prior course experience

4. A recent conversation with another teacher

5. Estimation of how well the students as a group are moving

6. Estimation of what the group can handle

7. Estimation of how well particular individuals in the class are moving

8. Estimation of what particular individuals can handle

9. Class dynamics and individual dynamics in class 
Moreover, the internal factors is someone internal related to the decision-making process itself, i.e. the internal structuring of decisions and the relationships of decisions to each other (Woods, 1996, p. 128). In addition, Borg (2003, p. 96) stated that internal factors occur when the teacher is making decisions about what to do in a course, lesson or classroom moment or what will teacher do at the first step, second step and so on. The internal factors are also shaped by teachers understanding about the knowledge of the material itself.

In the other hand, Borg (2003) states that there are some factors that shaped teachers' ability to bring their beliefs into classroom practices, those are social factors, psychological factors and environmental realities of the school and classroom. These factors include parents, principle requirements, the school, society, school mandates, classroom and school layout, school policies, colleagues, standardized tests and the availability of resources (p. 94). Those factors are some elements that influence teacher's thinking and action in the teaching learning process. It is because the factors above are considered by the teacher when reflecting their beliefs in the classroom.

\section{Multiple Intelligences based English Teaching}

Multiple intelligences theory is a theory proposed by Howard Gardner in 1983 about the definition of human intelligence and basic human intelligences types. This theory aims to redefined the means of human intelligences proposed by Alfred Binet in 1904 who stated that someone intelligence is determined by the result of IQ test that only emphasize on verbal ability and computational skill. Gardner (1983, cited in Hoerr, 2000) explained that human intelligence is the ability to solve the problems or to create the products that is valued in a society which focuses on using ability in a real life situation.

Garner also explained that there are nine types of basic human intelligences (Fachrurrazy, 2012, p.105), those are:

1. Linguistic Intelligence is the ability to perceive and generate spoken or written language.

2. Logical-mathematical Intelligence is the ability to appreciate and use numerical, abstract and logical reasoning to solve the problems.

3. Musical Intelligence is the ability to create, communicate and understand meanings made out of sound.

4. Spatial Intelligence is the ability to perceive, modify, transform and create visual and/or spatial images.

5. Bodily kinesthetic Intelligence is the ability to use all or parts of one's body to solve problems or create products.

6. Naturalist Intelligence is the ability to distinguish among critical features of the natural environment.

7. Interpersonal Intelligence is the ability to recognize, appreciate and contend with the feelings, beliefs, and intentions of other people.

8. Intrapersonal Intelligence is the ability to understand oneself, including emotions, desires, strengths and vulnerabilities and to use such information effectively in regulating one's own life.

9. Existential Intelligence is the ability to be sensitive to or have the capacity for conceptualizing or tackling deeper or larger questions about human existence.

Then, the theory of multiple intelligences is starting to be developed by the educators to be one of the popular approaches in language teaching. It is become the new innovation for language instruction by using students' strength to help them learn. Fachrurrazy (2012, p.105) stated that multiple intelligences approach view students not based on smart or no smart but in what 
way a student is smart. It means that smart is not only determined by how someone's got a good score on a test but it can be determined by how good someone learns in a variety of ways. In multiple intelligences theory people are showed that all students are smart, all students can learn.

Furthermore, Dastgoshadeh \& Jalilzadeh (2011, p.57) stated that multiple intelligences theory proposed that all people have different and unique intelligences, learning styles and weaknesses. Through the integration of multiple intelligences into teaching strategies, teachers are expected to improve the learning environments and increase innovations across the curriculum. The goal of multiple intelligences based English teaching is to help students to understand the lesson well through multiple modes of delivery. It is expected that through Multiple intelligences based instruction, teaching can be in multiple ways to cope with the students' different ways of learning (Dolati, Z., Tahriri, A. \& Danaye Tous, M., 2016, p.54).

\section{METHODOLOGY}

The research design of this study was descriptive qualitative in order to explore the contributing factors which shape teachers' beliefs on multiple intelligences based English teaching for young learners. The data were gathered through the interview session by conducting semi-structured interviews. In this study semi structure-interview is chosen by the writer because she will ask formulated questions then develop it in order to adapt with such situation in the field. Then, interviews were recorded, transcribed and analysed (Ary et al, 2010, p.438).

Moreover, the participants of this study were two primary English teachers who have been teaching with multiple intelligences based English teaching for more than 3 years in MI based private primary school. To analyse the data, the writer used the interactive model of data analysis by Miles \& Huberman (1984, p.22). The analysing process after collecting the data were reducing data, displaying data and drawing conclusion. In this part the writer collect the data from the interview process of the two primary teachers as the participants. In the next step, the writer selects the data, analyse it, and identify it. Then, she arranged all the data obtained in the form of description to create the final report. In final step, she draws a conclusion and creates the accurate findings.

\section{FINDINGS}

In this session we will explain the finding of the results and discuss it. The data are gathered from the interview results from English teachers of fifth grade. From the interview results we can see that the first contributing factors which shape teachers beliefs about MI based English teaching for young learners is internal factors. The internal factors relate to (1) teachers' learning experience, (2) teachers teaching experience and (3) their motivation to teach English based on students' multiple intelligences. Moreover, the second contributing Factors are the external factors. The external factors come from (1) school policies, (2) classroom management, (3) school training, (4) parents, (5) colleagues, (6) the availability of resources and media, (7) teachers' goal. The explanation of the findings will be explained below:

\section{Internal Factors}

In this part, the writer will explain the findings about the internal factors that contribute to shape the teachers beliefs toward the use of MI based English teaching. The internal factors come from teachers' learning experience, teachers' teaching experience and teachers' motivations in teaching with multiple intelligences based instruction. The findings are revealed by the English teachers from the interview process. 


\section{(1). Teacher's Learning experience}

Teachers' learning experience become a contributing factor which shape teachers beliefs about MI based English teaching for young learners. Their experiences in learning how to be an English teacher will lead them to find and adapt many methods, approaches and strategies to be implemented in the classroom.

From the interview results, a teacher explained that she knew about multiple intelligences theory when they were in the university but another teacher did not. However, they do not know the practice of it until they joined to this school which implemented multiple intelligences system in the instruction. As stated by teacher VA that she know about MI when she was a student in the university but she did know how to implement this theory into the classroom. Then, in the practice she feels difficult at the first time but she can adapt it well.

"I have known MI since college. Yes, I have known MI in theory but I don't know it in practice. The practice turns out to be" wow".

On the contrary, teacher DY explained that she did not know about this theory when she was studied at university but, she only knew it when she joined to this school.

"Since entering this school, previously, I did not know much about learning approach that uses the multiple intelligences theory when I was in college. I just found out when I was a teacher here, and learned about multiple intelligences systems."

From the explanation above, it can be conclude that teachers learning experiences are contributed to shape teachers' beliefs on multiple intelligences based English teaching for young learners. As a learner teacher, they are ready to learn and adapt many method, strategy or approach to be implemented in their teaching and learning process.

\section{(2). Teacher's Teaching experience}

Teachers' teaching experiences contribute to shape the teachers' beliefs toward the use of MI based English teaching. From the interview results, the teachers have been teaching in MI based private primary school for more than 3 years. They were implemented multiple intelligences system during that day up to now.

In this study, teacher VA has been teaching in the school for 3 years. She started teach use multiple intelligences system when she joined into the school. In applying multiple intelligences based instruction she was requested to be more creative in creating teaching activities. She also has to recognize the students' intelligences tendency to know their learning style. She explained what she feels when she teaches with MIS. She feels difficult and sad sometimes at the first time because she did not know much about the students' learning style, students' tendency of intelligence and students characteristic. However, as time goes by she used to it and feels happy and enjoy to teach the students with MIS. She said:

"I, sometimes there are some difficult times, sometimes there is also sadness, but I felt happier and easier. In the past there were a lot of difficulties in the beginning, at first I had to struggle, I didn't know the children well either. The main factor is that we don't know more about the nature or the characteristics of children but the more we know, the easier automatically. "

Moreover, she feels comfortable when she teach the students with multiple intelligence based instruction because she think that she gave the students' right for their needs in the teaching learning process. She thinks that teaching use multiple intelligences system makes the class atmosphere more alive. On the contrary, when she teaches with conventional method, she feels 
that the instruction will be bored and stagnant even though the conventional method will be easier for her to teach.

"From my point of view, it is easier to not use it, because it is indeed true that we are demanded to be creative, we are required to be susceptible to children, yes, we also need to know what kind of intelligence stands out more in every children's side. If the teachers do not use it, it can be called as conventional and it means they teach in a very comfort way. But in my opinion, from my heart I am determined to choose MI because it has given all of the children's rights. I pity children, in case the teachers choose the conventional approach, sometimes it causes stress, especially if there is a lot of homework from teachers. When we use a non-MI approach, learning will be boring. It is the opposite of the MI approach."

In a while, teacher DY stated that her teaching experiences use multiple intelligence system in this school, make her more creative as a teacher. It is because she has to match her teaching style with the students' learning style. She also has to find any strategy that fit the tendency of students' intelligences when creating learning activities in the classroom. She said:

"What I feel is, if the teacher has to be more creative. We must be able to find all kinds of ways and for sure we must first know what class this dominant child is. Now that's different from the child who adjusts the teacher, it's up to us. If this is the case, we must find a way to continue, look for activities that might vary from one week to another."

Moreover, she feels difficult at the first time but as a teacher, she has to learn and adapt to any kind of method, approach or strategy. As times goes by, she used to implement it in the teaching and learning process. She said:

"It used to be very difficult when I taught it at the beginning, because indeed we were never taught about this at all, right, I also don't have any background about this, right? But as time goes on, I get used to it because it has become habituation to us. And the demand for creativity here is very high, but the learning resources are everywhere around us."

Moreover, teacher DY explained that there is a different situation in the classroom when she teach use MIS and conventional teaching. In my class, the situation is a little crowded because the students are asked to be more active. She also described that the teaching learning process is fun, easy and understandable. She tried to leave out the boredom in the class by implementing games in each meeting. On the other hand, the class with traditional method is easy to control by the teacher. The students tend to be quite in the class and they become passive learners.

"If there are some differences in the class situation so if in MI the class situation cannot be expected to be safely controlled, it must be chaotic because the child is challenged for it, and no one is silent here. Then that's in terms of orderliness, but they have fun, they are mostly able to obtain the material easily because there was no burden, even though the entry is a little here. We are accustomed to do games when the KBM is less than 5 or 10 minutes left. The game is adjusted based on the lesson but it's not only inside the class, inside the class aka "ndekeng". Moreover, we can value how far the children understand the materials that have been taught. Here the lesson is relaxed but there must be a target that needs to be met. Well, the difference is that, if the conventional class tends to be orderly, the teacher is very good at a lot of materials and there are boredom there, I know just like that." 
From the interview results stated by teacher VA and teacher DY, their teaching experiences use multiple intelligence system in this school contributes much for their beliefs about MI based English teaching for young learners. They learn more how to understand the multiple intelligences system for instruction, its implementation, and its impact for students' achievement.

\section{(3). Motivation}

Teachers' motivation in implementing MI based English teaching becomes one of the factors that contribute their beliefs about MI based English teaching for young learners. Teacher VA stated that teaching with multiple intelligences system is challenging. She feels that she needs to solve something with MIS. Therefore, she is motivated to use MIS to teach her students. Some of the students are good in English but some of them are not. Therefore, she needs an approach to increase the students' ability with low achievement in English becomes more capable. With MI, she finds that students are all do good in English with their own way. She explained:

"Like I want to solve something, oh, this kid can't do it, this kid isn't able to do it, but with MI, the kid is able to do it. Oh, a child who is thought to be unable in academic, test, or written tasks, but they also can do in other tasks. As long as we use the appropriate approach for teaching, so it's really challenging. "

On the other hand, teacher DY state that her motivation to use MI in her teaching and learning process is because of the demand from the school. The school used MIS in its instruction; therefore, she is requested to teach with MIS. She thinks that teaching using MIS make her learn new knowledge every day. She increases her knowledge and her understanding for better instruction. She becomes a learner teacher, not only the students who learn but also the teacher. She said:

"The first is to fulfill the demands of work and the second is to enrich our knowledge by understanding MI. That's all. If in the past as far as I know, the teaching is just like that, but here it is really "wow".

From the interview results, teachers' motivation in teaching English using MIS becomes the contributing factor that shape teachers' beliefs about multiple intelligences based English teaching for young learners. Teachers' motivations shape the internal factors of the teachers to learn about MIS and implement it in the instruction to create an active learning.

\section{External factors}

The second contributing factors which shape teachers beliefs about MI based English teaching for young learners are external factors. The external factors relate to school policies, classroom management, school training, parents, colleagues, teachers' goal, the availability of resources and media. The data are gathered from the interview results from English teachers of fifth grade.

\section{(1) School policy}

In this session, the school policies are one of the factors that influence teachers' beliefs toward the use of MI based English teaching for young learners. The schools reasons to implement multiple intelligences system for its teaching and learning process shape the beliefs of the teachers to design their instruction appropriate with MIS. Teacher VA explained that school reasons implemented MIS in the instruction come from their view on the students' intelligences. The school policy sees that the students' ability is diverse. Therefore, they need a humanist approach to be implemented which can be adjusted with the various abilities of the pupils. The school policy in the input process is different from other schools. The difference 
comes from the input process of the students. The school did not hold a cognitive test as a requirement to join the instruction in the school. However, the school observed the students' habit and their ability to recognize students' tendency of intelligence. She said that:

"This is Ms., if here the input is different from the usual school, what I mean different is usually in other schools that I know, there is a test for entering the school. We have no special test to be accepted at this school. Because here it is indeed when children enter they are not tested academically but are observed from their psychological side, from their abilities, from intrapersonal side, interpersonal side, just observations and parents, their habits are observed to find out their intellectual tendencies. And based on those considerations, the MI is used here, the children were diverse, and usually for entering ordinary schools were academically tested because the children were those who were academically clever. If here there are so many types of children the lesson can't be done just like sitting quietly listening to conventional learning, it can't work like that. Thus, it is combined accordingly."

Moreover, teacher DY explained that school policies to use MIS for the instruction is showed by school committee's view about the humanist approach which can implemented for the students. The school committee sees that the humanist approach will cause to the fun instruction which will not burden the students. MIS is viewed as an appropriate approach to be implemented in an education institution. MIS concept believes that teachers have to adjust their teaching style with students' learning style. In this concept the students' learning style is showed from the students' tendency of intelligences. Therefore, the input process in the school is different from other schools. She said that:

"Because every student has different intelligence. All of them not only linguistic talented or math-logic talented. So, we have to make sure that the way of our teaching is appropriate with the students' intelligence. We must adjust to students not students who have to adjust to us. That is a more humanist approach and more suitable for fun learning. So children are not burdened."

From the explanation above, one of the factor that shape teachers' beliefs in teaching learning process is the school policies. In this case, the school policy use MIS as their approach influence all the elements of the school including teachers and their teaching style in teaching learning process.

\section{(2) School training}

The school training also plays an essential external factor that shaped teachers beliefs toward the use of MI based English teaching. In the training, the teachers are motivated to learn how to teach the students creatively, how to handle manage MI classrooms and how to handle the students with their multiple learning styles. Teacher DY stated that the school train the teachers about how to implement MI in the instruction by inviting the founder of MIS in Indonesia to train them. She also said that the coaching about MIS still run in the school every year but the current trainers comes from the internal foundation of the school.

"Oh, for that we have actually been off around 2 years ago because at that time Pak Munif was sick by chance so he couldn't fill out the training in Solo, then we changed him with Sayyid Haidar from Central Lazuardi to discuss about MI too until now. And for the training we still do it every year and take the central training from the central instructors we cannot just take any instructors."

Moreover, she stated that the discussion and the coaching about MI based learning implementation is also hold when they did a weekend meeting, a month meeting and a semester meeting. It is purposed to improve the teachers to master MI. she stated: 
"For the training, at any time at school there is training so that like once a week we have coaching. Maybe in that month, once every Friday, we have guidance every once in a month, we always mention MI. Then there is other trainings at the KBM meeting, every Wednesday. Then we have teaching technique every Tuesday. Yes indeed, even though it does not fully say this is MI training, but it is added there and also twice a year we have RAKER (a meeting in each semester), we will discuss MI because it is the basis of this school right, I want all teachers mastering MI."

On the contrary, teacher VA stated that the training about how to implement MI in the instruction only hold when she becomes a new teacher in her first year of teaching. She stated:

"At the beginning, for example the work meeting, but the meeting was right when I first entered So for example the teacher who just entered was explained what kinds of curriculum uses here. The learning process using "My Pals" books are tried by MI, because the characteristics of children are different, from the first work meeting, but that was on the first one a half year but after that, no, but still at each meeting we always discuss MI, also with other teachers, there are also the training aside from MI, like K13 from the education authorities".

In short, the training about MI becomes one of the external factor that influence teachers' beliefs. This training is purposed to educate the teachers how to implement MI based teaching for the students. It is also held to improve teachers' teaching quality. Therefore, the training contributes for the beliefs of the teachers even though there is a different experience when teachers join that training.

\section{(3) Parents}

Another external factor that influences teachers' beliefs toward the use of MI based English teaching is parents of the children. From the interview results, both teachers, teacher VA and teacher DY said that parent's reaction toward the use of MIS in the school showed positive results. The parents understand that their children have different learning style and different ability in learning. Therefore, they agree when the school use MIS as their based teaching approach to increase their children's achievement. Additionally, these positive reactions from the parents influence the beliefs of the teachers in implementing MI based instruction well. Teacher VA stated:

"Most of the students' guardians don't have problems, just fine, positive. Yes, that is possible, right because the children have different characteristics."

In addition, parents' reactions also influence teachers' beliefs on how they can improve their teaching through MIS and how they can give a brief understanding about MIS to the parents. Teacher DY stated:

"When they register here they understand that in this school they use MI, how these children they will study etc. So far the majority of student guardian responses are indeed very positive, or we can say that what they are looking for is here. But there are also some people who think that the lesson is very relaxed, especially for grade 1 and 2 because yes, it was our school. It is not cognitive oriented and we also give understanding to parents about that matter."

\section{(4) Colleagues}

Teachers are open to discuss each other about the implementation of MI based English teaching. They share their methods, difficulties, problems and the solutions of it with their colleagues. Especially, when they were becomes a new teacher at the school. Teacher VA stated: 
"I Iaught parallel at 5A and 5B. I usually share with teachers who are in "5th grade" too. For example, "how far have you finished the materials, Later, what kinds of activities do you want to do?" Usually that is all, the sharing. "

Additionally, teacher DY stated that sharing with other teachers will give her new idea how to teach the students with MIS in the classroom. She said:

"It is certain to work with other teachers because we need ideas or input from each other."

The school policy is also required them to discuss about the students, their ability and learning style and how to handle with the students' multiple intelligences. It is purposed to support each other for a better instruction. Therefore, the colleagues become one of the external factors that shape teachers' beliefs on MI based English teaching for young learners.

\section{(5) The availability of resources and media}

Multiple intelligences based English teaching encourages teachers to create strategy for their instruction creatively. Therefore, the open and easy access for the availability of resources and media in teaching with MIS is essential. It influences a lot for teachers beliefs in implementing multiple intelligences based English teaching in their instruction. Teacher VA said:

"'Media and learning resources are very important to support children's learning in the classroom. Because we are required to be creative and adjust to the material anyway. For the media I sometimes make it myself, sometimes I lend to other teachers. Sometimes children make the media on their own, for example, I give home project that later on it can be used for other materials. Sources of learning can be from the internet, can be from children themselves, can be from my pal's books which belong to the children. The determination of the theme is referred to "My pals" The others are additional."

In line with teacher VA, teacher DY stated that the availability of resources and media is important for her to help her strategy in the class and to help students to get a better visualization of the material.

"The media and learning resources are important for our learning. Because the media and learning resources will support the strategy that will be used in the classroom and it help teachers visualizing to the children as well. Then we adapt it to the material in the My Pals book and then we adjust it all again with the children's learning style. "

In conclusion, the availability of resources and media becomes one of the influencing factors to shape the teachers beliefs on MI based English teaching for young learners. It is because of the important of it in assisting the teachers' strategy in the classroom.

\section{(6) Goal}

In this part, the goal from the teachers will be explained to be one of the factors that shape teacher beliefs toward MI based instruction. The goal of the instruction forces teacher to work hard for the best teaching learning process. Teacher VA stated that her main goal is focused on persuading students to love to learn and want to learn. Her other target is making students feels fun, happy and enjoy their classroom moments. When the students love to learn and happy with their learning process, they will be ready to do the task in learning, such as speaking, writing, reading or listening. Even though the teacher did not ask them to do a task, they will ask it by themselves. She stated:

"Yes, that was like I said earlier, the target is that children want to learn, basically they want to learn, happy to learn. So if they want and are happy to learn for sure, the 
results will be good too, if they are told to speak, read, write or whatever. In sya Allah, they want to. Because the process is fun, the kids exclaim, they don't have to be told they will be responsive to be willing to do their jobs by themselves. "

In line with teacher VA, teacher DY also explained that her target for MI based instruction for the young learners is making a fun learning appropriate with their styles of learning. It is because MI based instruction process is effective for her students. She hopes that the students can understand more, there are no burdens in learning. They can go to school easily and having fun learning. She stated:

"On our own, children will get fun materials according to their learning styles. For KBM, using this MI is very effective. Hope they can understand more. And they don't have a burden. They can go to school easily and have fun here. "

In conclusion, the goal of the teachers becomes their expectation and target for their instruction process. Therefore, teachers' goal becomes one of the external factors that shape teachers' beliefs on MI based English teaching.

\section{DISCUSSION}

This part discusses the research findings of the study. It is also purposed to interpret the findings based on the theoretical point of view. Concerning the result of the previous section, it can be explained that there are some factors contribute to shape the teachers' beliefs toward the use of multiple intelligence based English teaching. Many theories explained how the teachers' beliefs become the fundamental framework to make a decision about what will they do in teaching (Bedir; 2010, Bingimlas \& Hanraham; 2010, Borg \& Busaidi; 2012, Fauziati; 2015). Additionally, teachers' beliefs are acquired from many factors and those factors can be influenced from anywhere. According to Woods (1996, p.128) there are two factors that influence and shape the teachers' beliefs. Those factors are the internal and the external factors. The writer identifies some internal and external factors that shape teachers' beliefs on the use of multiple intelligences based English teaching.

The internal factors come from someone internal conditions which affect the beliefs process (Woods, 1996, p. 128). In this study, the internal factor come from the teachers' learning experiences, teachers' teaching experiences and their motivation in teaching based on MI based instruction. Teachers' experiences in learning how to be an English teacher will lead them to find and adapt many methods, approaches and strategies to be implemented in the classroom. Teachers' own experiences as language learners contribute much in shaping their beliefs on teaching with multiple intelligences system in the instruction process. Their beliefs about teaching are the reflection of how they were taught.

However, in the findings, the teachers said that they did not know about the practice of MI based instruction until they join to teach in the current school which runs multiple intelligences system. Therefore, in the practice they feel difficult at the first time but they can adapt it well and develop themselves to apply a better instruction based on multiple intelligences methods. In this case, it showed that the teachers can adapt with any new methods and approach influences from their learning experiences when they studied how to be a teacher and how to teach the students with many methods or approaches or strategies.

The teachers' teaching experiences with MIS also contributes to shape their beliefs on multiple intelligences based English teaching. After years of teaching experiences with multiple intelligences system, teachers develop themselves how to enhance the learners' achievement through multiple intelligences based instruction. Their experiences in teaching using multiple 
intelligences method increase their ability in creating active learning. They are demanded to manage the students and classroom activities. They become more aware about the students strength and weaknesses through students' intelligences tendency and how to handle them. Moreover, they try their best to make fun and happy learning without forgetting about the essential of understanding and mastering the material. Therefore, their teaching experiences influences their beliefs about multiple intelligences based English teaching. Those explanations above are in line with Richardson (1996) statements that personal experiences, schooling and instruction experiences and formal knowledge experiences can affect strongly to teachers beliefs.

Another internal factor that contributes to shape the teachers beliefs is the teachers' motivation. Teachers motivation becomes the contributing factors to shape the teachers' beliefs on applying multiple intelligences based English teaching because of its challenge. The teachers are challenged to increase the students' ability and achievement in learning the language. Some of the students are good in English and some of them are not, therefore they feel that they need to solve it with multiple intelligences based instruction.

The external factors which shape the teachers beliefs on the use of multiple intelligences based English teaching in this study relate to school policies, school training, parents, colleagues, teachers' goal, the availability of resources and media (Borg, 2003, p.94). The school policy to use multiple intelligences system for its teaching and learning process become a contributing factor in shaping the teachers' beliefs on applying of multiple intelligences based English teaching. The school policy shape the teachers' beliefs to design their instruction based on the principle of multiple intelligences system. The different process to input the students, to run the teaching learning process and the output process influence the teachers' beliefs on how to create their instruction adjusting with multiple intelligences system.

The school training contributes to shape the teachers' beliefs because of its impact in implementing multiple intelligences based instruction. The school training coach the teachers how to manage an MI classes and the students' multiple ways of learning. Furthermore, teachers' colleagues are also influenced teachers' beliefs in implementing multiple intelligences. They shared each other's about their methods, difficulties, problems and the solutions in implementing multiple intelligences system for its instruction. Their colleagues' experiences influence them to run multiple intelligences system in their classroom.

Parents also play important factors that shape teachers beliefs on the use of MI based English teaching. Parents positive reactions toward the use MIS for their children education process influence teachers to give a best instruction for the students in the school. In addition, the availability of resources and media and its easy access influences teachers in shaping their beliefs on the use of MIS. It shaped the teachers' beliefs because of its important in assisting the teachers' strategy in the classroom.

Moreover, teachers' goals in implementing multiple intelligences system in the classroom shaped teachers' beliefs on the use of MIS. Teachers goals becomes teachers' target in implementing multiple based English teaching for the instruction process. Teachers' goals shaped the teachers beliefs to work hard for the best teaching and learning process using multiple intelligences based English teaching. The internal factors and the external factors mentioned above are in line with Xu $(2012, \mathrm{p} .1398)$ statement that teachers beliefs are formed by the accumulation of social history and culture, personal experience and education, teachers' teaching ability and the students. 


\section{CONCLUSION}

The explanation above showed some influencing factors that shaped teachers beliefs toward the use of multiple intelligences based English teaching. There are internal and external factors that shape teachers' beliefs on the use of multiple intelligences based English teaching. The internal factors relate to teachers learning Experiences, teachers' teaching experiences and teachers' motivation in teaching based on MI based instruction.

Furthermore, the external factors which shape the teachers beliefs on the use of multiple intelligences based English teaching in this study come from school policies, school training, parents, colleagues, teachers' goal, the availability of resources and media. Those factors influence teachers' ability to bring their beliefs into classroom the practices.

In addition this study are expected to be a source for other researcher about the factors and conditions which can shape someone beliefs in teaching, especially the beliefs about the implementation of multiple intelligences based English teaching at the instruction process. This study also expected to motivate English teachers to enhance their beliefs because their beliefs influence them in shaping their classroom actions. By knowing their contributing factors in shaping their beliefs, teachers are expected to enhance the students' achievement in language learning.

\section{References}

Armstrong, T. (2009). Multiple Intelligences in the Classroom (3rd Ed). Virginia, USA: ASCD (Association for Supervision and Curriculum Development).

Ary, D., et al. (2010). Introduction to Research in Education (4th ed.). Belmont: Wadsworth Cengage Learning.

Bingimlas, K. \& Hanrahan, M. (2010). The Relationship between Teachers' Beliefs and Their Practice: How the Literature Can Inform Science Education Reformers and Researchers. In M.F. Tasar \& G. Gakamkci (Eds.). Contemporary Science Education Research: International Perspectives (pp. 415-422). Ankara, Turkey: Pegem Akademi.

Borg, S. (2003). Teacher Cognition in Language Teaching: a Review of a Research on What Language Think, Know and Believe and Do. Language Teaching. 36 (2), 81-109. DOI: 10.1017/S0261444803001903.

Borg, S. \& Al-Busaidi, S. (2012). Teachers' Beliefs and Practice Regarding Learning Autonomy. ELT Journal Vol. 66, 283-292.

Bedir, H. (2010). Teachers' Beliefs on Strategies Based Instruction in EFL Classes of Young Learners. ProcediaSocial and Behavioral Sciences, 2(2), pages 5208-5211. doi: 10.1016/j.sbspro.2010.03.847

Bingimlas, K. \& Hanrahan, M. (2010). The Relationship between Teachers' Beliefs and Their Practice: How the Literature Can Inform Science Education Reformers and Researchers. In M.F. Tasar \& G. Gakamkci (Eds.). Contemporary Science Education Research: International Perspectives (pp. 415-422). Ankara, Turkey: Pegem Akademi.

Celik, S. (2015). Managing the Classes by Using Multiple Intelligences Instruction. Journal of Education. 4 (1) ISSN 2298-0172

Chatib, M. (2013). Sekolahnya Manusia. Bandung: Kaifa

Dastgoshadeh, A. \& Jalilzadeh, K. (2011). Multiple Intelligences-based Language Curriculum for the Third Millenium. International Conference on Education, Research and Innovation IPEDR. Vol.18. pp 57-62

Dolati, Z., Tahriri, A., \& Danaye, T. (2016). EFL Teacher's Practice of Multiple Intelligences and the Role of Their Teaching Experience. International Journal for Teachers of English, 20, 90-115.

Fachrurrazy. (2012). Teaching English as a Foreign Language for Teachers in Indonesia. Malang: State University of Malang Press.

Fauziati, E. (2015). Teaching English as A Foreign Language: Principle and Practice. Surakarta: Era Pustaka Utama. Gardner, H. (1999). Intelligence Reframed: Multiple Intelligences for the 21 ${ }^{\text {st }}$ Century. New York, NY: Basic Books. 
Faidah, R. T., Fauziati, E., \& Suparno. (2019). Exploring The Influencing Factors Of Teachers' Beliefs Toward The Use Of Multiple Intelligences Based English Teaching. Advances in Social Sciences Research Journal, 6(6) 137-150.

Hoerr, T. R. (2000). Becoming A Multiple Intelligences School. Virginia, USA: ASCD (Association for Supervision and Curriculum Development).

Ismail, Z.H. \& Singh A. (2007). Teachers Beliefs: Definitions and Assumptions. Perkembangan Professional DP Jilid 7, Bil.1/2007.

Miles, B. H. \& Huberman, A. M. (1984) Qualitative Data Analysis: A sourcebook of New Methods. California: SAGE Publication, Inc.

Nicholson, K. \& Nelson. (1998). Developing Students' Multiple Intelligences. New York: Scholastic Proffesional Books.

Pajares, F. (1992). Teachers' Beliefs and Educational Research: Clearing up a Messy Construct. Review of Educational Research 62 (2), 307-332.

Richardson, V. (1996). The role of Attitudes and Beliefs in Learning to Teach. In J. Sikula (Ed.), Handbook of Research on Teacher Education (2nd edn.,pp. 102-119). New York: Macmillan.

Woods, D., (1996). Teacher Cognition in Language Teaching: Beliefs, Decision-making and Classroom Practice. Cambridge: Cambridge University Press.

$\mathrm{Xu}$, L. (2012). The Role of Teachers Beliefs in the language Teaching-Learning Process. Theory and Practice in Language Studies, Vol.2, No. 7, pp. 1397-1402.

Yero, J.L. (2002). Teaching in Mind: How Teacher Thinking Shapes Education. Hamilton, MT: MindFlight Publishing. 